\title{
Agrowisata Berkelanjutan Berbasis Kopi di Satria Agrowisata Desa Manukaya, Kecamatana Tampak Siring, Kabupaten Gianyar, Bali (Studi Evolusi Pariwisata)
}

\section{Febrytha Nur Azizaha, 1 , I Putu Anom a, 2}

1 febrytha23@gmail.com, 2putu_anom@unud.ac.id

a Program Studi Sarjana Destinasi Pariwisata, Fakultas Pariwisata,Universitas Udayana, Jl. Dr. R. Goris, Denpasar, Bali 80232 Indonesia

\begin{abstract}
Agro-tourism is an alternative tourism activity that relies on plantations and agriculture as its main attraction. Along with the development of tourism, agro-tourism has now become an economic driving commodity for the surrounding community, so that agro-tourism is increasingly taken into account in the world of tourism. The development of an agro-tourism can not be separated from the evolutionary process that occurs through various stages of the beginning of the tourist attraction built until now. This study aims to determine the evolution of developments in Satria Agrowisata. The research method used is descriptive qualitative by conducting data collection techniques through online interview as primary data, and conducting online observations as secondary data. The results show that Satria Agrowisata can adapt well to the various changes that exist and continue to innovate in order to survive in the world of tourism until now. In Darwin's theory of evolution, he put forward two key words in his theory, natural selection and adaptation. Natural selection as a mechanism for evolutionary change, and adaptations that occur in its development over time.
\end{abstract}

Keyword: Evolution, Agrotourism, Satria Agrowisata, Bali.

\section{PENDAHULUAN}

Agrowisata merupakan salah satu alternatif kegiatan pariwisata berbasis alam yang memanfaatkan potensi pertanian maupun perkebunan sebagai daya tarik utamanya. Perkembangan agrowisata ditunjukkan melalui evolusi yang mengarah pada terwujudnya pembangunan pariwisata berkelanjutan (Suistainable of Tourism Development) yang artinya bahwa pembangunan dapat didukung secara ekologis dalam jangka panjang sekaligus layak secara ekonomi, adil secara etika dan sosial terhadap masyarakat.

Menurut McKercher (1999), destinasi pariwisata terkenal karena kompleksitas non-linear dan dinamisnya. Maka dari itu, suatu daya tarik wisata akan selalu mengalami perkembangannya. Perkembangan agrowisata ditunjukkan melalui evolusi yang mengarah pada terwujudnya tahap pengembangan pariwisata berkelanjutan yaitu prinsip yang berpijak pada keseimbangan aspek dan pengembangan serta berorientasi ke depan (jangka panjang). Berkenaan kepada nilai manfaat yang besar bagi masyarakat setempat, prinsip pengelolaan aset tidak boleh merusak sumber daya alam, dan dapat berkelanjutan jangka panjang baik secara sosial budaya maupun ekonomi.

Dalam teori evolusi Darwin (1859), ia membuat konklusi bahwa organisme yang mampu beradaptasi terhadap lingkungan mampu meneruskan sifat unggul kepada keturunannya melalui proses reproduksi. Darwin menyadari bahwa adaptasi berkembang seiring berjalannya waktu sehingga Darwin perlu menjelaskan mekanisme evolusi.
Darwin mengajukan kata "seleksi alam" sebagai mekanisme perubahan evolusioner. Seleksi alam merupakan proses yang terus berlangsung karena lingkungan terus berubah. Berdasarkan teori dan pandangan terhadap evolusi tersebut, landasan ini dipergunakan untuk menganalisa perkembangan suatu daya tarik wisata melalui proses evolusi, karena pariwisata tidak akan dapat terjadi secara berkelanjutan jika tidak melalui berbagai proses pengembangan didalamnya, berlaku pula pada pariwisata serta kebudayaan yang mengikutinya akan senantiasa mengalami dialektika seiring berjalannya waktu. Proses evolusi memiliki tiga proses pokok yaitu; struggle for life atau perjuangan hidup, the survival of the fittest atau kemampuan untuk bertahan melalui keunggulan, dan natural selection atau seleksi alam.

Tampak evolusi dalam ilmu pariwisata digunakan untuk menggambarkan perubahanperubahan akibat sektor pariwisata di suatu destinasi wisata (Anom, dkk., 2019). Seperti evolusi kawasan destinasi wisata yang dominan melihat perubahan fisik (Butler, 1980) dan evolusi pariwisata sebagai turimemorfosis yang dominan melihat non fisik (Mahagangga, dkk., 2018).

Bali merupakan salah satu destinasi di Indonesia yang menyuguhkan keindahan alamnya sebagai daya tarik wisata. Banyak wisatawan yang berkunjung ke Bali dikarenakan ingin menikmati pemandangan alam yang masih asri. Dengan berbagai macam tempat wisata di Pulau Bali ini memberikan pengaruh yang sangat positif terhadap Produk Domestik Regional Bruto (PDRB) Provinsi Bali, hal ini dibuktikan dengan 
pemasukan terbesar PDRB Provinsi Bali terletak pada Sektor Pariwisata. Perkembangan PDRB pada Triwulan I 2011 menunjukan peningkatan dari tahun sebelumnya, yaitu mencapai 17,47 Triliyun, dimana sektor perdagangan, hotel, dan restoran mendominasi PDRB Bali dengan nilai tambah sebesar 5.32 Triliyun dan diikuti dengan peningkatan pada sektor lainnya. Sektor Pariwisata Bali ini sudah sangat terbukti menciptakan iklim positif pada pertumbuhan ekonomi Provinsi Bali. Akan tetapi, tantangan yang dihadapi khususnya bagi penduduk Bali adalah tetap menjaga dan menciptakan suasana yang aman dan nyaman bagi calon wisatawan untuk meninkmati keindahan Bali dan tentunya menciptakan pariwisata yang berkelanjutan (Bulletin Tata Ruang, 2011).

Salah satu wisata yang telah dikembangkan dalam bentuk agrowisata adalah Satria Agrowisata yang terletak di Desa Manukaya, Kecamatan Tampaksiring, Kabupaten Gianyar, Bali, yang kini semakin berkembang seiring meningkatnya jumlah wisatawan.

Perkembangan terbaru Satria Agrowisata untuk mewujudkan pariwisata berkelanjutan dalam proses evolusinya, Desak Putu Padmidewi, dkk (2019) menyebutkan adanya kesesuaian antara harapan dan kenyataan pada penerapan Tri Hita Karana di Satria Agrowisata melalui kacamata sosial. Untuk mempertahankan keberlangsungan hidup Satria Agrowisata, strategi pengembangan usaha pada Satria Agrowisata dilakukan dengan mempertahankan harga dan kualitas untuk memperluas jangkauan pemasaran, melakukan perekrutan karyawan dibidang tertentu, meningkatkan mutu pelayanan, meningkatkan kreatifitas untuk produk baru yang lebih diminati konsumen, meningkatkan upaya pemasaran produk melalui kegiatan promosi yang intensif dan efisien, membuat Website dan Sosial media mengenai Satria Agrowisata, dan membuat kemasan produk yang lebih menarik (Putu Marita Cakatini Rosyanta, dkk : 2018).

Berkenaan dengan hal tersebut, Satria Agrowisata menggunakan kreatif lokal sumber daya dan upaya menghasilkan semangat kerja serta gaya hidup dengan transformasi yang terstruktur melalui beberapa aktor lokal daripada dari titik nodal terpusat. Sehingga kolaborasi muncul sebagai properti utama dari perubahan jaringan transformasional.

Atas latar belakang ini, dilakukan penelitian untuk mengetahui bagaimana evolusi perkembangan dari agrowisata kebun kopi di Satria Agrowisata dari awal hingga kini yang sudah menjadi daya tarik wisata dan banyak dikunjungi oleh wisatawan, serta mengetahui upaya apa yang dilakukan oleh Satria Agrowisata untuk meningkatkan performa dan produktifitas dalam pariwisata berkelanjutan.

\section{METODE PENELITIAN}

Penelitian ini berlokasi di Jl Raya Kintamani, Desa Manukaya, Kecamatan Tampaksiring, Kabupaten Gianyar, Bali. Jarak Satria Agrowisata dari pusat kota Denpasar adalah $37 \mathrm{~km}$ dengan kisaran waktu satu jam dari Kota Denpasar. Pemilihan lokasi dilakukan dengan memiliki tujuan tertentu (purposive) dikarenakan kawasan tersebut sudah menjadi daya tarik wisata yang berbasis agrowisata. Untuk memperoleh data, penelitian ini menggunakan dua sumber, yaitu data primer yang merupakan data berupa kata-kata dan tindakan diperoleh langsung dari orang-orang yang diwawancarai (informan), Moleong (2000: 112), serta data sekunder yang tidak langsung memberikan data kepada peneliti yang sifatnya mendukung data primer yang dapat berupa jurnal, tabel statistik, buku, dan referensi lain terkait dengan masalah penelitian (Sugiyono, 2008:402). Informan pada penelitian ini adalah Dewa Artawan selaku pengelola Satria Agrowisata. Untuk menganalisis data menggunakan teknik deskriptif kualitatif yaitu upaya yang dilakukan dengan jalan bekerja dengan data, mengorganisasikan data, memilah-milahnya menjadi satuan yang dapat dikelola, mensintesiskannya, mencari dan menemukan pola, menemukan apa yang penting, apa yang dipelajari dan memutuskan apa yang diceritakan kepada orang lain (Moleong, 2012).

\section{HASIL DAN PEMBAHASAN}

Satria Agrowisata yang berdiri sejak 2011 telah mengalami evolusi dan berbagai perkembangan. Kondisi awal Satria Agrowisata dalam kegiatan pariwisatanya sangatlah jauh dari kata sempurna, namun sedikit demi sedikit Satria Agrowisata kini dapat berkembang dan telah menjadi tujuan agrowisata utama di wilayah Tampaksiring. Tentunya, evolusi perkembangan tersebut ditunjukkan melalui perubahan-perubahan maupun inovasi yang telah dilakukan untuk menunjukkan eksistensinya serta perjuangan tetap bertahan pada lingkungan pariwisata.

Menurut Darwin (1859), Struggle for Life merupakan perjuangan keras individu dalam beberapa periode kehidupannya. Perjuangan hidup dilakukan dengan penyesuaian diri atau adaptasi melalui perubahan sosial dan fisik yang mengikuti keadaan zaman maupun lingkungan. Perubahan sosial Satria Agrowisata meliputi perubahan material dalam segi ekonomi dan immaterial di sisi sosiokultural atau sosial budaya. Dalam segi ekonomi, dengan adanya kegiatan pariwisata di daerah mereka tentu sangat membantu tingkat perekonomian. Untuk diketahui, seluruh karyawan Satria Agrowisata adalah masyarakat lokal dimana masyarakat lokal merupakan sumber daya manusia yang paling kompeten. Pengelola mengungkapkan, pada awal Satria Agrowisata berdiri di tahun 2011 hingga tahun 2019, jumlah karyawan yang dimiliki Satria Agrowisata adalah 13 orang. Kini, di tahun 2020, Satria Agrowisata telah memiliki 22 orang karyawan dalam operasionalnya. Ini membuktikan bahwa Satria Agrowisata melibatkan masyarakat melalui partisipasi aktif untuk berkontribusi serta sadar akan membangun pariwisata di daerahnya. Disisi lain, terjadi perubahan pula pada segi sosial budaya. Dengan adanya pariwisata di daerah mereka dimana para wisatawannya berasal dari berbagai belahan dunia, masyarakat yang bekerja di Satria Agrowisata 
mengajarkan bahasa asing kepada anak-anak serta warga sekitar dan kemudian mereka dapat mempraktekannya di Satria Agrowisata ketika bertemu dengan pengunjung dari luar negeri serta menambahkan wawasan mereka. Hal ini merupakan proses difusi pada evolusi yang menggambarkan adanya perubahan sosial budaya.

Kemudian, munculnya perkembangan teknologi dan informasi hingga saat ini memudahkan calon wisatawan untuk menggali informasi mengenai produk-produk wisata yang ada di destinasi. melalui media travel blog dan online social media, salah satu media online tersebut adalah Tripadvisor. Wisatawan dapat memberikan berbagai ulasan (review) terkait dengan destinasi yang telah mereka kunjungi seperti dalam tabel 1 di bawah:

Tabel 1. Ulasan wisatawan pada media sosial Tripadvisor.

\begin{tabular}{|c|c|}
\hline Nama/Asal/Waktu & Ulasan \\
\hline $\begin{array}{c}\text { Liu S } \\
\text { Lithuania } \\
\text { Maret, } 2016\end{array}$ & $\begin{array}{l}\text { Pengalaman yang luar bisa } \\
\text { untuk mencoba luwak kopi } \\
\text { pertama kalinya. Mereka juga } \\
\text { menawarkan free tasting } \\
\text { untuk } 12 \text { jenis kopi dan teh, } \\
\text { anda juga bisa melihat } \\
\text { bagaimana kopi Luwak } \\
\text { dibuat. Kunjungan yang } \\
\text { sangat berarti. }\end{array}$ \\
\hline $\begin{array}{c}\text { Euphs J } \\
\text { Jerman } \\
\text { Oktober, } 2017\end{array}$ & $\begin{array}{l}\text { Layak dikunjungi untuk } \\
\text { melihat bagaimana petani } \\
\text { lokal menanam kopi dan } \\
\text { mengolahnya di desa } \\
\text { setempat, kita juga bisa } \\
\text { melihat hewan luwak secara } \\
\text { langsung. }\end{array}$ \\
\hline $\begin{array}{c}\text { Elaine M } \\
\text { Norwegia } \\
\text { Maret, } 2018\end{array}$ & $\begin{array}{l}\text { Tempat ini harus dikunjungi. } \\
\text { Karyawan yang mereka } \\
\text { miliki sangatlah ramah. Saya } \\
\text { senang bisa mencoba sampel } \\
\text { minuman dari macam- } \\
\text { macam teh dan kopi yang } \\
\text { ditawarkan Lingkungan } \\
\text { alamnya yang masih asli } \\
\text { membawa kita merasakan } \\
\text { seperti di "hutan" yang } \\
\text { menjadikan hal ini lebih seru } \\
\text { dan menyenangkan. }\end{array}$ \\
\hline $\begin{array}{c}\text { Viz } \\
\text { California } \\
\text { Februari, } 2019\end{array}$ & $\begin{array}{l}\text { Saya sangat senang bisa } \\
\text { belajar tentang bagaimana } \\
\text { biji kopi difermentasikan dan } \\
\text { diproses, saya juga suka } \\
\text { dengan teh yang ditawarkan } \\
\text { gratis oleh karyawan. }\end{array}$ \\
\hline $\begin{array}{c}\text { Fussy H } \\
\text { Mexico } \\
\text { Maret, 2020 }\end{array}$ & $\begin{array}{l}\text { Mereka membawa kita } \\
\text { melakukan tour dan } \\
\text { menjelaskan tentang } \\
\text { perkebunannya. Kami } \\
\text { mendapatkan pengalaman } \\
\text { wisata yang baik. }\end{array}$ \\
\hline
\end{tabular}

Kemudahan teknologi saat ini, media sosial berperan sangat besar dalam mengenalkan Satria
Agrowisata secara luas dan global. Melalui Tripadvisor, secara tidak langsung ini merupakan bentuk promosi 'mulut ke mulut' terhadap wisatawan yang ingin berkunjung ke Satria Agrowisata. Hingga kini, Satria Agrowisata telah mendapatkan 293 ulasan yang membantu meningkatkan jumlah wisatawan. Ditambah lagi, tren mengenai kopi yang sedang marak saat ini dalam pasar pariwisata maupun industri lainnya, menjadi kesempatan emas Satria Agrowisata dalam destinasi pariwisata sebagai agrowisata berbasis kopi.

Perubahan fisik nyata pertama yang dilakukan oleh Satria Agrowisata adalah merubah packaging atau kemasan bungkus biji kopi dan teh yang merupakan produk suvenir Satria Agrowisata di tahun 2014. Memodifikasi produk-produk yang ada di destinasi wisata adalah bentuk kreatifitas sebagai upaya menunjukkan eksistensi melalui inovasi. Kedua, pengelola mengungkapkan bahwa pada tahun 2018 adanya penambahan lahan pada Satria Agrowisata yang sebelumnya 40 are menjadi 1 hektare. Lahan ini diperluas untuk menambahkan berbagai fasilitas pendukung serta sarana dan prasarana di Satria Agrowisata. Ditahun yang sama pula, Satria Agrowisata mengikuti tren digital dengan membangun atraksi wisata baru yaitu berupa swing serta spot-spot foto instagrammable yang pada saat itu sedang populer di kalangan wisatawan. Wisatawan akan mengabadikan kegiatannya di Satria Agrowisata dan secara tidak langsung mempromosikan Satria Agrowisata di media sosial sehingga menciptakan citra yang baik dan tentunya menarik para calon wisatawan.

Menurut Spencer (1864), individu dalam populasi hanya perlu memiliki sifat yang paling menguntungkan untuk bertahan hidup di suatu lingkungan. Satria Agrowisata memiliki tujuan utama yaitu memprioritaskan service atau pelayanan melalui hospitality yang baik antara host dengan guest. Pengelola membeberkan bahwa hospitalitas memiliki peranan utama sebagai keunggulan produk untuk bertahan demi bersaing dengan komponen pariwisata lainnya, hal ini dilakukan dengan selalu menjaga hubungan baik dengan wisatawan serta pemandu wisata (guide) dan service yang harus selalu ditingkatkan. Selain itu, Satria Agrowisata mempunyai keunggulan dalam bidang landscape atau panorama alam yang tidak dimiliki oleh agrowisata lain di sekitarnya. Dengan total lahan 40 are yang kini dimilikinya, Satria Agrowisata mempunyai berbagai fasilitas, sarana dan prasarana didalamnya yang mendukung kenyamanan wisatawan dalam aktivitas wisatanya. Satria Agrowisata memiliki tagline "Bali Cat Poo Chino" yang dijelaskan oleh pengelola berarti Cat = kucing, Poo $=$ kotoran luwak, Chino $=$ tambahan kata keterkaitan untuk dunia kopi. Tagline ini bertujuan sebagai strategi promosi yang dilakukan oleh Satria Agrowisata. Menurut Hermawan Kartajaya (2005), strategi ini disebut dengan positioning dan diferensiasi dalam membangun sebuah brand. Pada aspek positioning, wisatawan yang berkunjung akan mengingat tagline yang dimiliki oleh Satria Agrowisata. Kemudian, hal ini yang menjadi pembeda (diferensiasi) suatu destinasi terhadap destinasi lainnya. Sehingga, tagline tersebut menjadi sebuah upaya branding dalam pemasarannya. 
Seleksi alam yang terjadi pada Satria Agrowisata berkaitan dengan adanya perkembangan teknologi yang kini semakin pesat kemajuannya. Pengelola menuturkan, pada tahun 2017 penggilingan kopi (coffee processing) untuk produk kopi di Satria Agrowisata telah beralih dengan memanfaatkan kecanggihan teknologi berupa mesin penggilingan kopi. Dimana sebelumnya penggilingan kopi tersebut dilakukan secara manual dan tradisional oleh penduduk asli. Namun, proses tradisional ini tidak ditinggalkan begitu saja saat Satria Agrowisata sudah beralih menggunakan penggilingan kopi dengan mesin canggih, melainkan tetap dipertahankan hanya untuk kegiatan tour kopi kepada wisatawan. Menurut Herkovite (dalam Jurnal Analisis Pariwisata, 2010: 93), fenomena ini disebut dengan istilah kelangsungan dalam perubahan, yaitu bergerak menuju perubahan kearah kemajuan tetapi tetap mempertahankan identitasnya.

Pengelola menuturkan bahwa Satria Agrowisata berencana akan membuka restoran guna melengkapi fasilitas yang ada, sehingga wisatawan dapat merasa lebih nyaman. Peluang ini dilihat oleh pengelola karena masih adanya ruang yang bisa digunakan untuk fasilitas tambahan lainnya

\section{KESIMPULAN}

Evolusi agrowisata berkelanjutan berbasis kopi di Satria Agrowisata meliputi, perjuangan hidup (Struggle for Life) Satria Agrowisata ditunjukkan melalui penyesuaian diri pada perubahan sosial dan fisik.. Adanya perkembangan teknologi terhadap media sosial turut andil dalam mendatangkan wisatawan mancanegara yang berdampak positif pula pada eksistensi Satria Agrowisata, sehingga hal tersebut semakin menyerap banyak tenaga kerja lokal yang mana menyejahterakan perekonomian masyarakat lokal pula. Inovasi-inovasi yang dilakukan oleh Satria Agrowisata juga menyesuaikan terhadap perubahan perkembangan zaman, inilah bukti bahwa Satria Agrowisata selalu berjuang dalam mempertahankan keberadaannya di industri pariwisata, bahwa ada usaha eksistensi dan tetap adaptif terhadap lingkungan yang dinamis dan kerap berubah. Kedua, keunggulan (The Survival of The Fittest) Satria Agrowisata dibandingkan dengan agrowisata lain yang berada di daerahnya adalah lansekap pemandangan alam dan lahan Satria Agrowisata yang lebih luas. Selain itu, Satria Agrowisata selalu mempertahankan pelayanan yang baik dalam bentuk service dan hospitality, yang memang sudah menjadi ciri khas Satria Agrowisata. Ketiga, pada seleksi alam (Natural Selection), Satria Agrowisata telah mengubah metode atau cara untuk memproses pengolahan kopi (coffee processing) dari tradisional menjadi pengolahan kopi berteknologi mesin dalam proses produksinya. Kedepannya, Satria Agrowisata berencana untuk membangun restoran guna sebagai penambahan fasilitas yang ada di Satria Agrowisata sehingga wisatawan dapat nyaman dan menetap lebih lama.

\section{DAFTAR PUSTAKA}

Anom, I. P., \& Mahagangga, I. G. (2019). Handbook Ilmu Pariwisata : Karakter dan Prospek. Denpasar: Prenada Media.

Butler, R. W. (1980). The concept of a tourist area cycle of evolution: implications for management of resources. Canadian Geographer/Le Géographe canadien, 24(1), 5-12.

Darwin, C. (1859). On The Origin of Species by Means of Natural Selection. London: J. Murray.

Darwin, C. (2010). The Origin of Species by Means of Natural Selection. (6th, Ed.) Cambridge University Press.

Kartajaya, H. (2005). Hermawan Kartajaya On Positioning. Jakarta: Mizan.

McKercher. (1999). A Chaos Approach To Tourism. Tourism Management, 20.

Mahagangga, I., \& Oka, G. A. Suryawan, Ida Bagus. Anom, I Putu dan Kusumanegara, I Made. 2018. Evolusi Pariwisata di Indonesia, Turismemorfosis di Kabupaten Badung, Kabupaten Banyuwangi dan Kabupaten Luwu Timur.

Moleong. (2000). Metode Penelitian Kualitatif. Bandung: Remaja Rosdakarya.

Moleong. (2012). Metodologi Penelitian Kualitatif. Bandung: PT Remaja Rosdakarya.

Padmidewi, D. P., \& dkk. (2019). Penerapan Tri Hita Karana pada Manajemen Satria Agrowisata di Kecamatan Tampaksiring, Kabupaten Gianyar.

Pembangunan Berkelanjutan : Penerapan Masa Saat Ini dan Kemasa Datang. (2011). Bulletin Tata Ruang.

Rosyanta, P. M., \& dkk. (2018). Strategi Pengembangan Usaha Agroindustri Kopi Luwak Pada Satria Agrowisata di Kabupaten Gianyar.

Sendra, I. M. (2010). Jurnal Analisis Pariwisata, 10.

Spencer, H. (1864). The Principles of Biology. New York: Appleton.

Sugiyono. (2008). Metode Penelitian Kuantitatif, Kualitatif dan $R \& D$. Bandung: Alfabeta.

Taufik. (n.d.). Teori Evolusi Darwin: Dulu, Kini, dan Nanti. Jurnal Filsafat Indonesia.

Tripadvisor.com. (n.d.). Retrieved Mei 03, 2020, from https://www.tripadvisor.com/Attraction_Reviewg1025505-d3470645-Reviews-Satria_AgrowisataTampaksiring_Gianyar_Regency_Bali.html

Tripadvisor.com. (2016, March). Retrieved May 03, 2020, from https://www.tripadvisor.com/Attraction_Reviewg1025505-d3470645-Reviews-or35Satria_AgrowisataTampaksiring_Gianyar_Regency_Bali.html\#REVIEWS

Tripadvisor.com. (2017, October). Retrieved May 03, 2020, from https://www.tripadvisor.com/Attraction_Reviewg1025505-d3470645-Reviews-or5-Satria_AgrowisataTampaksiring_Gianyar_Regency_Bali.html\#REVIEWS 
Vol. 8 No 2, 2020

Tripadvisor.com. (2018, March). Retrieved May 03, 2020, from https://www.tripadvisor.com/Attraction_Reviewg1025505-d3470645-Reviews-or10-

Satria_Agrowisata-

Tampaksiring_Gianyar_Regency_Bali.html\#REVIEWS

Tripadvisor.com. (2019, February). Retrieved May 03, 2020, from https://www.tripadvisor.com/Attraction_Reviewg1025505-d3470645-Reviews-or5-Satria_AgrowisataTampaksiring_Gianyar_Regency_Bali.html\#REVIEWS

Tripadvisor.com. (2020, March). Retrieved May 03, 2020, from https://www.tripadvisor.com/Attraction_Reviewg1025505-d3470645-Reviews-Satria_AgrowisataTampaksiring_Gianyar_Regency_Bali.html\#REVIEWS 